\title{
The West Needs to Rethink Its Strategic Goals for Asia
}

\begin{abstract}
When the West had its "End of History" moment at the end of the Cold War, it failed to recognize the return of Asia to the center stage of world history. Now, rather than blaming the rise of China for the myriad of problems it faces, the West should rethink its strategy for dealing with Asia.
\end{abstract}

Few thinkers can speak about global governance with as much authority as Kishore Mahbubani. A former President of the United Nations Security Council, Permanent Secretary of Singapore's Foreign Ministry, and Dean of the renowned Lee Kuan Yew School of Public Policy at the National University of Singapore, he has been named "the muse of the Asian century" and listed among the top 100 most influential public intellectuals in the world by the Financial Times, Foreign Policy and Prospect.

In his latest book, due this year, Mahbubani plans to tackle the rising tensions between the United States and China, and the former diplomat have some frank advice for the West. As he explains, the election of President Donald Trump and the launching of a trade war with China should be viewed as symptoms of the refusal of the US to accept its inevitable decline as the world's number one economy. Instead of howling at the moon, the US should embrace a more minimalist and strategic approach to foreign policy to maximize its interests in an era of Asian dominance.

Q: In your last book, Has the West Lost It?, you point out that there has been a remarkable improvement in the quality of life of people across the world over the past 30 years, but public discourse in the West has become increasingly pessimistic. What is behind this contradiction?

A: The great paradox, as I emphasize in the book, is that the dramatic improvement in the human condition is the result of the generous gifts of the West to the rest, especially the gift of reasoning. And, frankly, future historians looking back at our time would say that the 30 years from roughly 1980 to 2010 saw probably the most dramatic improvement in living standards in human history. So, this should be a moment of great celebration in the West-the great Western project of improving the human condition has succeeded.

Originally publised in Forbes, February 27, 2019 
Paradoxically, the West has never been more depressed. I think the one reason for this is that the West made a huge strategic mistake at the end of the Cold War in 1989: it was seduced by the essay of Francis Fukuyama, "The End of History?," which basically said that the West had defeated the Soviet Union and it could just switch on autopilot, whereas the rest of the world needed to make strategic adjustments to this new world.

Fukuyama's essay did a lot of brain damage to the West. He put the West to sleep precisely at the moment when China and India were waking up. For 1800 of the past 2000 years, the world's two largest economies have always been those two countries. The last 200 years have been a major historical aberration. And, of course, all aberrations eventually come to a natural end.

But what no one could have foreseen in 1989 was the speed at which China and India have re-emerged. In 1980, in purchasing power parity terms, the United States' share of global GDP (gross domestic product) was $21.7 \%$ and China's share was $2.3 \%$, which means that China's share was around $10 \%$ of the US. By 2014 , astonishingly, China's share had become bigger. That's why it's such a dramatic period in human history.

Q: You outlined two key factors that have destabilized the West: first, a decline in real wages following the entry of China and Eastern Europe into the global trading system; and second a realization that national governments are becoming powerless to control the forces of globalization. Which of these is the most important?

A: They're both related. I think just as the West made a big strategic mistake at the end of the Cold War, another strategic mistake was made in 2001 when 9/11 happened. I was actually in Manhattan on $9 / 11$, so I understood the shock that was felt by America. What happened as a result of 9/11 was that America decided its biggest strategic challenge was going to come from the Islamic world, so it launched wars in Afghanistan and Iraq.

That was a mistake because the most important strategic event that happened in 2001 was not 9/11 but China's admission into the World Trade Organization. China's entry injected 800 million workers into the global capitalist system and-as Joseph Schumpeter taught us - that would lead to creative destruction. So, it's not surprising that in the decade that followed, lots of people in the US and Europe lost their jobs. But because the elites were benefiting from the expansion of the global economy, they didn't notice that their own masses were suffering.

So, I would say that future historians will see that the election of Donald Trump in 2016 was not a surprise, but an inevitable result of the elites not taking care of their masses. The median income of the American worker had not improved for 40 years. That's shocking. Everything is tied together to China's admission to the WTO. 
Q: Recently, many commentators in the US have been debating whether it was a "mistake" to allow China to join the World Trade Organization in 2001. What is your view on this debate?

A: There's a wonderful Western expression, 'there's no point shutting the door after the horse has bolted.' This is a classic demonstration of that saying. China has already joined the WTO; it is part of the global trading system and is incredibly integrated into it. There is nothing you can do about that.

What the West, and especially the US, needs to do is to adjust to this new competitive global system. I think it can adjust and can do well, but it is a question of working with rather than against China, which is why the current trade war is misguided. In fact, any sensible Western economist will tell you that America's trade deficit is not a result of China playing unfairly. It is actually the result of the US having the global reserve currency, which allows it to consume more than it produces. That is actually a privilege.

Q: In a recent article for Project Syndicate, you said you were struck during a recent sabbatical in the US by how decisively sentiment among the US elite has turned against China. What has caused this change?

A: I don't know, it's mystifying, but it has happened. I think there is a growing awareness that China is becoming bigger and stronger. Even though Americans don't like talking about America becoming number two, subconsciously they must realize that America is moving toward that status. Instead of looking in the mirror and asking what mistakes you have made, it's always easier to find a scapegoat, and China is the obvious one. The danger is that when you look for a scapegoat, you ignore the core structural issues that America has to deal with in this new era.

\section{Q: How receptive should China be to the US's complaints about its economic and trade practices?}

A: I think the Chinese should figure out which complaints are valid, and which are invalid. The invalid one is that the bilateral deficit is the result of the Chinese playing unfair - that is not true at all. In fact, the trade deficit paradoxically helps American workers in some ways. Even though their income has not gone up, they can buy more things, more cheaply thanks to Made-in-China products.

But, of course, there are also valid complaints. First, China may have been stealing intellectual property from American firms. Second, China has insisted that if American firms invest in China, they are to transfer technology to China. Third, there are non-tariff barriers. China has lowered its tariff barriers and fulfilled its WTO obligations, but there are non-tariff barriers that have hindered Western exports to China.

I think what China needs to do is respond with a certain generosity of spirit because China has done very well thanks to the West opening up its markets. Now, China can reciprocate by opening up its markets even more. That would also give the US and Europe greater strategic interest in maintaining good ties with China. 


\section{Q: The US is increasingly focusing its ire on China's Made in China 2025 strategy. What is your view on this strategy?}

A: I think it's legitimate for China to aspire to become a technological superpower in its own right. Frankly, I think that China is going to succeed. The US should not complain about what China is doing, and instead, ask itself what the American response should be. But here, the ideology of people like US Trade Representative Robert Lighthizer-who believes that all government-led industrial policies don't work-gets in the way.

If industrial policies don't work, then why not allow this one to fail? If you complain about it, that suggests you believe it's going to work. Now, if it's going to work in China, why doesn't the United States launch its own comprehensive national strategy to maintain its technological lead? Instead of complaining about Made in China 2025, they should have a Made in America 2025.

\section{Q: If China does emerge as the world's leading economy, how do you expect China to reshape the global order?}

A: Just as America is reluctant to face the prospect of China overtaking them, I think the Chinese are reluctant to face the prospect of becoming number one. The Chinese should think more about this because it's very important that China makes a big effort to reassure the world that they're going to maintain the current rules-based order that the West has given the world. This is essentially what Xi Jinping promised in his two speeches in Geneva and Davos in January last year. And that's the message that needs to be repeated by China to the world.

It would be wise for China to strengthen the WTO, the United Nations, the International Monetary Fund and the World Bank, but that will require that the West gives up control. There was a rule created over 50 years ago that said the head of the International Monetary Fund should always be European and the World Bank leader should always be American. That rule was credible when the West's share of global GDP was overwhelming, but when your relative share of the global economy declines, and the most dynamic economies are in Asia, why are you disqualifying Asians from running these two organizations?

\section{Q: How should the US and Europe position themselves in a global system dominated by Asia?}

A: Europe and the US need to face the fact that the last two centuries of Western dominance have been a historical aberration, and that aberration is coming to a natural end. They need to be ready to deal with a world in which they remain strong, but in which their relative share of global GDP has gone down. If your share of GDP goes down, you need to adopt a new strategic approach, and what I suggest in Has the West Lost it? is a new "three-m" strategy for the West.

The first is "minimalist." The West should ask itself: should it get involved in so many wars? Should it be intervening in Afghanistan, Iraq, Libya, Syria, Yemen, and so on? The Chinese haven't fired a shot in 40 years, since the end of the war with Vietnam in 1979, whereas even during the last year of the presidency of Barack 
Obama, a peaceful man who won the Nobel Peace Prize, America dropped 26,000 bombs on seven countries. That's crazy.

The second " $\mathrm{m}$ " is multilateral. Here, I build on the advice of former President Bill Clinton, who told his fellow Americans that if you can conceive of a world in which America is number two, then surely it is in America's interests to strengthen the world's multilateral order, which will then constrain the next number one, China. The tragedy is that although the world's multilateral institutions are the West's gift to the world, it is America with the silent collusion of Europe that has been weakening them. That's unwise.

And the third " $m$ " is Machiavellian, which is just short for "be pragmatic." You want to focus on your own priorities and do what's important for you. So, for example, Europe's long-term challenge is not going to come from Russia-Russian tanks are not going to invade Germany. But what you're going to get is a demographic explosion in Africa that's going to be a challenge. You're going to get more refugees coming, and we've seen what has happened to Europe politically because of refugees. Therefore, it is in Europe's interest to see Africa develop, and the best partner to develop Africa is China. America is frightened of China's influence in Africa and condemns Chinese investment there, and the Europeans, because they're subservient to America, also criticize China. But China's long-term strategic investment in Africa is a gift to Europe. That's what I mean about thinking in Machiavellian terms about where your interests lie.

Open Access This chapter is licensed under the terms of the Creative Commons AttributionNonCommercial-NoDerivatives 4.0 International License (http://creativecommons.org/licenses/bync-nd/4.0/), which permits any noncommercial use, sharing, distribution and reproduction in any medium or format, as long as you give appropriate credit to the original author(s) and the source, provide a link to the Creative Commons license and indicate if you modified the licensed material. You do not have permission under this license to share adapted material derived from this chapter or parts of it.

The images or other third party material in this chapter are included in the chapter's Creative Commons license, unless indicated otherwise in a credit line to the material. If material is not included in the chapter's Creative Commons license and your intended use is not permitted by statutory regulation or exceeds the permitted use, you will need to obtain permission directly from the copyright holder.

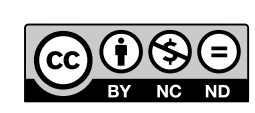

